\title{
The impact of the mTOR inhibitor sirolimus on the proliferation and function of pancreatic islets and ductal cells
}

\author{
C. T. Bussiere • J. R. T. Lakey • A. M. J. Shapiro • \\ G. S. Korbutt
}

Received: 15 March 2006 / Accepted: 22 June 2006 / Published online: 9 August 2006

(C) Springer-Verlag 2006

\begin{abstract} of sirolimus on this tissue.

C. T. Bussiere · J. R. T. Lakey $\cdot$ A. M. J. Shapiro

G. S. Korbutt $(\bowtie)$

Surgical-Medical Research Institute,

1074 Dentistry/Pharmacy Centre, University of Alberta,

Edmonton, AB, Canada

e-mail: Korbutt@ualberta.ca

J. R. T. Lakey • A. M. J. Shapiro · G. S. Korbutt

Department of Surgery, University of Alberta,

Edmonton, AB, Canada

J. R. T. Lakey • A. M. J. Shapiro

Clinical Islet Program, University of Alberta,

Edmonton, AB, Canada

C. T. Bussiere $\cdot$ G. S. Korbutt

Stem Cell Network of Canada,

Ottawa, ON, Canada
\end{abstract}

Aims/hypothesis The Edmonton Protocol for islet transplantation has provided hope for type 1 diabetic patients. However, this protocol requires lifelong immunosuppression, specifically sirolimus, a cellular antiproliferate. The effect of sirolimus on human pancreatic ductal cells (HDCs) is not known. This may be important since HDCs are believed to be islet precursors. Since neonatal porcine islets (NPIs), which contain many ductal precursor cells, could be a potential clinical source of islets, we also tested the effects

Methods HDCs $(n=4)$, NPIs $(n=9)$ and human islets $(n=5)$ were cultured with and without sirolimus $(20 \mathrm{ng} / \mathrm{ml})$ for 6 days. Results HDCs and NPIs cultured with sirolimus showed a 50 and $28 \%$ decrease, respectively, in cell number relative to control $(p<0.05)$. Control cultures expanded 1.65- and 2.44fold relative to time 0 . Decreases in cell number of sirolimus-treated HDCs were not due to apoptosis as measured by TUNEL staining. No functional effects on

human islets or NPIs were observed following static incubation with high glucose. Treatment of syngeneically transplanted and naïve BALC/c mice with sirolimus resulted in altered OGTT profiles with prolonged elevation of hyperglycaemia and weight gain. There was no difference in graft and organ insulin content between treatment groups. Conclusions/interpretation Our results indicate that sirolimus decreases ductal cell numbers in culture and alters glucose-stimulated insulin secretion in vivo. The administration of sirolimus to islet transplant recipients is likely to impair graft function as a result of decreasing ductal neogenesis and induction of insulin resistance.

Keywords Ductal cell $\cdot$ Human islet $\cdot$ Neonatal porcine islet . Sirolimus
Abbreviations
CK cytokeratin
GSIS glucose-stimulated insulin secretion
HBSS Hanks' balanced salt solution
HDC human pancreatic ductal cell
ITS insulin-transferrin-selenium
mTOR mammalian Target Of Rapamycin
NPIs neonatal porcine islet
TUNEL TdT-mediated dUTP nick-end labelling

\section{Introduction}

The clinical success of islet transplantation has provided an effective treatment for type 1 diabetic patients [1, 2]. Key elements for this success are the immunosuppressive protocol and transplantation of sufficient islet cell mass. Sirolimus, tacrolimus, and daclizumab are administered to 
transplant recipients to prevent islet graft rejection [3]. While this cocktail is free of steroidal drugs, which are known to have diabetogenic side effects [2], these agents may still affect the long-term function and survival of human islet grafts.

Several studies have investigated the effects of these immunosuppressive agents on beta cell function in human cell lines [4], rodent beta cells [5] and human beta cells [68]. These studies have shown that high doses of tacrolimus and sirolimus can cause significant exocytosis of cellular insulin [4], inhibition of insulin secretion upon stimulation by glucose $[5,8]$ and induction of apoptosis in both beta and alpha cells [6]. A recent clinical update of patients with long-term islet grafts shows that graft function diminishes over a 5-year period [1], necessitating exogenous insulin administration for the maintenance of tight glycaemic control. Graft function as demonstrated by persistent Cpeptide secretion is maintained, but the amount of insulin generated by the graft is no longer sufficient to maintain euglycaemia in the absence of usually small amounts of supplemental injected insulin. This reduction in insulin production may be the result of beta cell death coupled with impaired beta cell regeneration.

Finegood et al. [9] reported that the average life span of a beta cell is 1 to 3 months. Therefore dynamic beta cell turnover occurs within the pancreas to maintain a critical mass of functional beta cells. This also suggests that beta cell turnover occurs within islet grafts to maintain longterm function after transplantation. The source of pancreatic beta cell progenitor cells remains unknown. Using a genetic lineage tracing approach, Dor et al. reported that adult pancreatic beta cells are formed by self-duplication rather than differentiation from an undifferentiated stem cell [10]. Others have suggested that pancreatic ductal cells can serve as multipotent progenitor cells and that external stimuli can direct the differentiation of these cells to endocrine, acinar, or mature ductal cell phenotypes [11-15]. Other investigators have shown that the population of bone marrow or spleen cells may contain stem cells that can differentiate into beta cells [16-18].

The working hypothesis of our group is that ductal cells are the beta cell progenitors within the pancreas, contributing via neogenesis to the generation of new beta cells. We have recently shown that islet recipients who receive greater numbers of ductal cells within islet grafts have better graft function at 2 years post transplant as measured by acute insulin response to glucose [19]. Since ductal progenitors within the grafts may contribute to long-term graft function, it is important to determine the effect of immunosuppressive agents on these cells. Indeed, long-term immunosuppression may reduce graft function either by direct drug effects on the beta cells themselves or by effects on ductal cell progenitors that are transplanted with the islets (ductal cells form $20-30 \%$ of islet grafts) [19].

Sirolimus is a non-specific antiproliferative drug administered to patients receiving islet grafts. Sirolimus inhibits the clonal expansion of activated lymphocytes by interacting with the mammalian target of rapamycin (mTOR), inhibiting progression from the G1 to the $\mathrm{S}$ phase of the cell cycle [20]. Since the proteins bound by sirolimus are not unique to $\mathrm{T}$ cells, it is possible that sirolimus exerts this antiproliferative effect on other cell types. Studies have shown that sirolimus inhibits proliferation of coronary artery smooth muscles, hepatic stellate cells, small lung cancer cells, mouse proximal tubular cells and pancreatic cancer cells [21-25]. If sirolimus inhibits the proliferation of pancreatic duct cells or even existing beta cells within the islet grafts, this drug may impede new beta cell formation and thus limit graft longevity and function.

In the present study we have evaluated the effect of sirolimus on the function and proliferation of human pancreatic ductal cells (HDCs) and human islet cells. We have also tested the effects of sirolimus on neonatal porcine islets (NPIs). NPIs constitute a potential source of cells for clinical transplantation because of their inherent ability for proliferation and differentiation [26]. Recently, we provided the first evidence that allogeneic NPIs can reverse diabetes in a large animal model $[27,28]$.

\section{Materials and methods}

Study ethics

All experimental protocols used in this study were approved by the Research Ethics Board of the University of Alberta.

\section{Cell preparation}

\section{Human}

Human pancreases were removed from cadaveric donors, who had previously given informed consent, and processed according to previously described protocols [29]. Briefly, pancreata were stored in chilled University of Wisconsin solution before islet isolation. Islet isolation, gradient purification and tissue collection was performed as previously described for human islets $[2,30]$. For the in vitro insulin secretion experiments fresh $(n=3)$ or cryopreserved $(n=2)$ (donor ages 24-64 years) human islets were cultured in non-tissue-culture-treated plates for 2 to 3 days with RPMI 1640 medium (Gibco/Invitrogen, Burlington, ON, Canada) + insulin-transferrin-selenium (ITS)/BSA with $10 \%$ FCS prior to experimentation. 
Following islet purification, the ductal/acinar fraction was collected and washed three times with Hanks' balanced salt solution (HBSS; Mediatech Sigma-Aldrich, Oakville, ON, Canada) supplemented with $0.5 \%$ BSA (fraction V; Sigma). This fraction ( $n=4$; donor ages $11-67$ years) was cultured in suspension for 4 to 6 days with RPMI 1640 medium supplemented with $1 \%$ ITS/0.5\% BSA. Medium was exchanged at day 1 post culture and every 2 days thereafter. At the end of the culture period these preparations are composed of $68 \%$ cytokeratin (CK)-19, 16\% amylase, and $1 \%$ beta cells [31].

Pig

The isolation method for NPIs has been described [26]. Briefly, pancreases from Landrace-Yorkshire neonatal pigs (1-3 days old, 1.5-2.0 kg body weight) were removed and digested in $2.5 \mathrm{mg} / \mathrm{ml}$ of collagenase (Sigma). After filtration $(500 \mu \mathrm{m})$, cells were cultured for 6 days in HAMs F10 medium (Gibco) containing $10 \mathrm{mmol} / 1$ glucose, $50 \mu \mathrm{m}$ isobutylmethylxanthine (ICN Biomedicals, Montreal, QC, Canada), 0.5\% BSA, $2 \mathrm{mmol} / \mathrm{l}$ L-glutamine, $10 \mathrm{mmol} / \mathrm{l}$ nicotinamide (BDH Biochemical, Poole, UK), $100 \mathrm{IU} / \mathrm{ml}$ penicillin, and $100 \mu \mathrm{g} / \mathrm{ml}$ streptomycin. The medium was replaced every second day. After this culture period, the NPIs are routinely composed of $35 \%$ endocrine and $57 \%$ ductal endocrine precursor (CK7-positive) cells [26].

\section{Mouse}

Islets were isolated from BALB/c mice (purchased from The Jackson Laboratory, Bar Harbor, ME, USA); pancreases were distended with collagenase solution $(1 \mathrm{mg} / \mathrm{ml})$, surgically removed and digested. Following dextran gradient centrifugation, islets were picked off gradient interfaces, washed with HBSS and cultured overnight in Hams F10 [32].

\section{Cell expansion and characterisation}

After isolation and 4 to 6 days of culture [31] HDCs were cultured at $\sim 1.5 \times 10^{5}$ cells/well with and without 10 or 20 ng/ml sirolimus (Rapamune; Wyeth-Canada Laboratories, Markham, ON, Canada). NPIs (535 aggregates/well) were cultured as experimental cultures with $20 \mathrm{ng} / \mathrm{ml}$ of sirolimus added to the base media or as control cultures grown in base media alone. All cells were cultured in 12well tissue-culture-treated plates with RPMI 1640 (Gibco) and HEPES buffer, sodium pyruvate, $100 \mathrm{IU} / \mathrm{ml}$ penicillin, $100 \mu \mathrm{g} / \mathrm{ml}$ streptomycin, 10\% FBS, 2-beta-mercaptoethanol and $20 \mathrm{ng} / \mathrm{ml}$ endothelial growth factor and basic fibroblast growth factor (Invitrogen) to induce cell proliferation. Cell preparations were assessed for cell number by measuring DNA content at time 0 and day 6 of culture. We have previously shown that human islet cells contain $6.6 \mathrm{pg}$ DNA/cell [31] whereas NPI cells have $7.1 \mathrm{pg}$ DNA/cell [26]. Cellular insulin content and cellular composition of the NPI cultures were also characterised at these timepoints.

\section{Cell characterisation}

To determine cell number, aliquots of the cell suspension were measured in triplicate for total cellular DNA content using a fluorometric assay (Hoefer DyNa Quant 200; Amersham Pharmacia Biotech, San Francisco, CA, USA) as described previously [26]. Insulin content was measured after cellular extraction by RIA (porcine) or by ELISA (human) [26].

The cellular composition of NPI and HDC cultures was determined by immunohistochemistry using the avidinbiotin complex-3,3 diaminobenzidinetetrahydrochloride method. Briefly, cellular aggregates were dissociated into single cell suspensions and adhered to histobond slides (Marienfeld Glassware, Bad Mergentheim, Germany). Slides were fixed in Bouin's fixative for $12 \mathrm{~min}$ before storage at $4^{\circ} \mathrm{C}$ in $70 \%$ ethanol. Cells were quenched with $20 \% \mathrm{H}_{2} \mathrm{O}_{2} /$ methanol followed by microwave antigen retrieval for $\mathrm{CK} 7$ and 19 in sodium citrate. Primary antibody concentrations were as follows: 1/1,000 guinea pig anti-porcine insulin (Dako, Glostrup, Denmark), 1/50 mouse anti-human CK19 (Dako), 1/200 mouse anti-human CK7 (Dako). Antibodies to CK7 and 19 were used as markers for pancreatic ductal epithelial-type cells as previously described [33]. All biotinylated secondary antibodies were obtained from Vector Laboratories (Burlingame, CA, USA) and used at a concentration of $1 / 200$. Single cell counts were performed on 500 cells per sample and percentages calculated.

Apoptosis in control and sirolimus-treated HDCs was quantified using TdT-mediated dUTP nick-end labelling (TUNEL) staining. Single cells were adhered to histobond slides and fixed as described above. Cells were stained for CK19 to identify ductal cells using mouse anti-human CK19 (1:25; Dako) and labelled using Cy3-conjugated antimouse IgG (Jackson Immunoresearch Laboratories, West Grove, PA, USA). Next, the apoptotic nuclei were labelled with fluorescein isothiocyanate-dUTP (Roche, Laval, Quebec, Canada) using the TdT enzyme (Deadend Fluorometric TUNEL System; Promega, Madison, WI, USA). The stained slides were analysed using fluorescent microscopy and cells were counted as described above.

\section{Islet secretory activity}

Human islets and NPIs were suspension-cultured in $79-\mathrm{cm}^{2}$ dishes with $10 \mathrm{ml}$ of RPMI + ITS/BSA, 10\% FCS (human islets) or Hams F10 (NPIs), with $20 \mathrm{ng} / \mathrm{ml}$ of sirolimus 
included in experimental cultures. Control samples were cultured in base media. All cultures were maintained at $37^{\circ} \mathrm{C}\left(5 \% \mathrm{CO}_{2}, 95 \%\right.$ air $)$ in humidified air for 6 days, with medium changed every second day. Samples were taken at day 0 and day 6 for analysis of DNA and insulin content, glucose-stimulated insulin secretion (GSIS) and immunohistochemical composition.

Human islet and NPI secretory response to glucose were determined using static incubation assay [34]. Islet cell aliquots were washed with Hams F10 media without glucose and incubated for $120 \mathrm{~min}$ in $1.5 \mathrm{ml}$ of Hams media with either 2.8 or $20 \mathrm{mmol} / \mathrm{l}$ glucose. The supernatant was then sampled and assayed for insulin using ELISA (human) or RIA (porcine). The insulin content of the supernatant was expressed as a percentage of the total content (i.e. tissue plus medium). Stimulation indices were calculated by dividing the amount of insulin released at $20 \mathrm{mmol} / \mathrm{l}$ glucose by that released at $2.8 \mathrm{mmol} / \mathrm{l}$ glucose [26].

In vivo studies

\section{Effect of sirolimus on mouse islet graft function}

We transplanted 500 mouse islets that had been cultured for 1 day under the left kidney capsule of halothane-anaesthetised diabetic BALB/c mice (The Jackson Laboratory). Diabetes (glycaemia $>8.4 \mathrm{mmol} / \mathrm{l}$ ) was induced using $275 \mathrm{mg} / \mathrm{kg}$ body weight of streptozotocin (Sigma) injected intraperitoneally 2 days prior to transplantation. Transplanted mice were randomly separated into two groups control (untreated) and experimental (sirolimus-treated). Sirolimus treatment consisted of daily i.p. injection of $0.2 \mathrm{mg} / \mathrm{kg}$ sirolimus commencing the day after transplant and continuing for 26 days. Blood glucose levels were monitored weekly between 08:00 and 11:00 hours. An OGTT [26] was performed $48 \mathrm{~h}$ prior to graft removal on recipients that had achieved normoglycaemia (blood glucose $\leq 8.4 \mathrm{mmol} / \mathrm{l}$ ). After a 6 -h fast, a bolus of $50 \%$ dextrose $(3 \mathrm{mg} / \mathrm{g}$ body weight) was administered intragastrically to non-anaesthetised mice. Tail vein blood samples were obtained at 0,15 , 30, 60, 90 and $120 \mathrm{~min}$. Nephrectomy of the graft-bearing kidney was performed and the insulin content of the graft was determined after organ extraction by RIA.

\section{Effect of sirolimus on native pancreatic islet function}

Naïve BALB/c mice were divided into control $(n=11)$ and experimental $(n=11)$ groups. Experimental animals received a daily i.p. injection of sirolimus $(0.2 \mathrm{mg} / \mathrm{kg})$ for 26 days as detailed above and control animals received daily injections of saline. Blood glucose was monitored weekly and OGTT tests were performed at day 26 to assess pancreatic islet function. Pancreases were removed $48 \mathrm{~h}$ post-OGTT and organs assayed for insulin content. In a subset of animals $(n=4)$, whole blood was collected post-OGTT into EDTAtreated tubes via cardiac puncture and sirolimus content was measured by RIA.

Statistical analysis

Data are expressed as mean \pm SEM of $n$ independent observations. Statistical significance was calculated with a two-tailed unpaired Student's $t$ test or a one-way ANOVA in the case of multiple comparisons.

\section{Results}

Sirolimus inhibits proliferation of human pancreatic ductal cells and NPIs

Monolayers of HDCs were cultured for 6 days in medium containing no sirolimus (control) and either 10 or $20 \mathrm{ng} / \mathrm{ml}$ sirolimus. Human ductal cells cultured in control media showed a 1.65-fold expansion (increase in cell number) relative to time 0 , while in sirolimus-treated HDCs expansion was inhibited and cell number relative to time 0 decreased (Fig. 1). With sirolimus treatment, cell expansion was inhibited relative to control by $53 \%$ with $10 \mathrm{ng} / \mathrm{ml}$ and $50 \%$ with $20 \mathrm{ng} / \mathrm{ml}$ sirolimus $(p<0.05)$. A dose of $20 \mathrm{ng} / \mathrm{ml}$ sirolimus was maintained in subsequent experiments, based upon the target trough levels in human islet transplantation (12-15 $\mathrm{ng} / \mathrm{ml}$ for the first 3 months and $7-10 \mathrm{ng} / \mathrm{ml}$ thereafter) and in vivo experimental models [1, 2]. Decreases in the cell number of sirolimus-treated HDCs

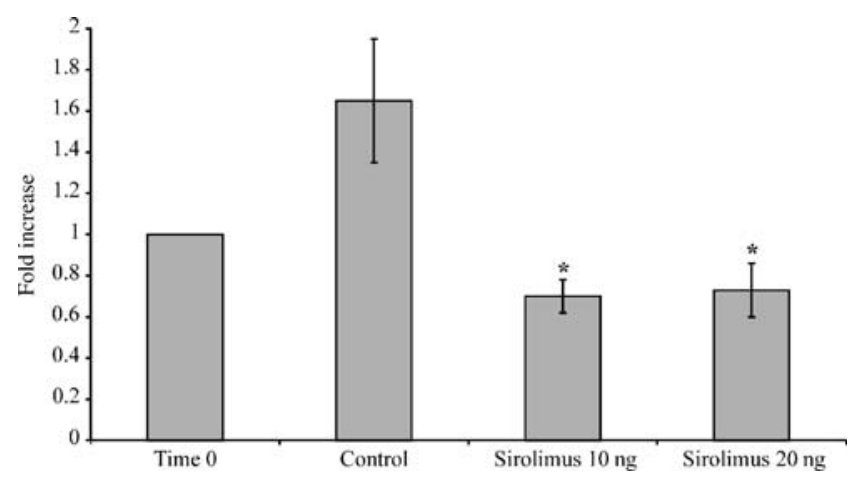

Fig. 1 The effect of sirolimus on pancreatic ductal cell expansion in vitro. Human ductal cell-enriched preparations were cultured in RPMI+ (20 ng/ml endothelial growth factor, fibroblast growth factor and $10 \%$ FCS) with and without (control) (10 or $20 \mathrm{ng} / \mathrm{ml})$ sirolimus for 6 days ( $n=4$ in each treatment group). Time 0 represents the initial number of cells in culture while bars for control and sirolimus-treated cells represent the change in cell number (fold increase) of cultures relative to the time 0 values. Statistical significance of differences were calculated by one-way ANOVA. ${ }^{*} p<0.05$ vs control group 
Table 1 The effect of sirolimus on the fold expansion and cellular composition of neonatal porcine islets

\begin{tabular}{lllll}
\hline Condition & Treatment & Positive cells (\%) & \multirow{2}{*}{ Fold increase } \\
\cline { 5 - 5 } & & Insulin-positive cells & CK7-positive cells & \\
\hline Pig & Time 0 & $14.64 \pm 2.12(5)$ & $29.21 \pm 1.93(5)$ & 1 \\
& Control & $7.17 \pm 2.07(5)$ & $47.78 \pm 6.80(5)$ & $2.44 \pm 0.62(9)$ \\
& Sirolimus & $7.68 \pm 2.55(5)$ & $41.30 \pm 14.20(5)$ & $1.77 \pm 0.59(9)^{*}$ \\
\hline
\end{tabular}

Values are means $\pm \operatorname{SEM}(n)$. In each experiment NPIs were cultured with or without (control) $20 \mathrm{ng} / \mathrm{ml}$ sirolimus for 6 days and islets were then assessed for cell composition and number (see 'Methods'). Time 0 represents the initial number of cells in culture

${ }^{*} p<0.05$ for difference relative to control-treated samples

were not due to drug-induced cell death as measured by TUNEL staining for apoptosis following 6 days of drug treatment. Control cultures showed that $19.27 \pm 3.52 \%(n=2)$ of CK19-positive ductal cells were undergoing apoptosis, compared with $17.55 \pm 7.05 \%(n=2)$ of CK19 cells in sirolimus-treated cells.

Monolayers of NPIs were cultured on tissue-culturetreated plates for 6 days in medium containing no sirolimus (control), or $20 \mathrm{ng} / \mathrm{ml}$ sirolimus. NPIs expanded in number under both control and sirolimus treatment conditions relative to time 0 (Table 1). Control-treated samples showed a $2.44 \pm 0.62$-fold increase and sirolimus-treated samples a $1.77 \pm 0.59$-fold increase in cell number relative to time 0 . Relative to control cultures, sirolimus treatment significantly reduced cell number to $28 \%$ of control $(p<0.05)$. Examination of cell composition showed that there was differential expansion of cell types; with a decrease in insulin-positive cells after 6 days of culture and an increase in CK7-positive ductal cells regardless of treatment (Table 1).

Sirolimus does not alter in vitro function of human islets or NPIs

The secretory activity of human islets cultured in the presence or absence of $20 \mathrm{ng} / \mathrm{ml}$ sirolimus was tested by comparing the percentages of cellular insulin that were released at low glucose $(2.8 \mathrm{mmol} / \mathrm{l})$ and high glucose
(20 mmol/l). No statistically significant differences were noticed in the amounts of insulin secreted at low and high glucose between treatment groups. The stimulation index, a measure of islet responsiveness to glucose, was not significantly different in samples at time 0 , or in control- or sirolimus-treated human samples (Table 2). Stimulation indices of control- and sirolimus-treated cultures were $3.51 \pm 1.91(n=5)$ and $2.40 \pm 0.65(n=5)$, respectively, which was slightly, though not significantly, elevated against time 0 values, $1.42 \pm 0.12(n=4)$.

The insulin secretory activity of NPIs cultured for 6 days in suspension with medium containing $20 \mathrm{ng} / \mathrm{ml}$ sirolimus was not different from controls (Table 2). Stimulation indices of control and sirolimus-treated cultures were $3.01 \pm 0.86$ and $1.98 \pm 0.33$, respectively, which was not statistically different from time 0 values of $1.96 \pm 0.34$.

Sirolimus impairs the function of syngeneic BALB/c mouse islet grafts and innate pancreatic islets

To examine the effect of sirolimus in vivo, BALB/c mouse islets were implanted beneath the kidney capsule of diabetic BALB/c mice and sirolimus treatment was administered as described (see 'Methods' section). Sirolimus had no effect on the daily blood glucose of animals, and animals in both treatment groups were normoglycaemic by 1 week post transplantation (Fig. 2). OGTT tests demonstrated that mice that received daily injections of sirolimus had elevated

Table 2 Effect of sirolimus on glucose-stimulated insulin secretion of human islets and NPIs

\begin{tabular}{llcrl}
\hline \multirow{2}{*}{ Condition } & Treatment & \multicolumn{2}{l}{ Insulin secretion (\% content) } & \\
\cline { 3 - 5 } & & $2.8 \mathrm{mmol} / \mathrm{l}$ glucose & $20 \mathrm{mmol} / \mathrm{l}$ glucose & Stimulation index \\
\hline Human islet & Time 0 & $7.52 \pm 1.82(4)$ & $10.74 \pm 2.91(4)$ & $1.42 \pm 0.12(4)$ \\
& Control & $4.96 \pm 2.26(5)$ & $14.71 \pm 7.64(5)$ & $3.51 \pm 1.91(5)$ \\
Pig & Sirolimus & $5.02 \pm 0.99(5)$ & $13.79 \pm 4.76(5)$ & $2.40 \pm 0.65(5)$ \\
& Time 0 & $2.47 \pm 0.52(4)$ & $4.31 \pm 0.14(4)$ & $1.96 \pm 0.34(4)$ \\
& Control & $0.46 \pm 0.06(4)$ & $1.35 \pm 0.36(4)$ & $3.01 \pm 0.86(4)$ \\
& Sirolimus & $0.53 \pm 0.05(4)$ & $1.07 \pm 0.24(4)$ & $1.98 \pm 0.33(4)$ \\
\hline
\end{tabular}

Values are means $\pm \operatorname{SEM}(n)$. Stimulation indices were calculated by dividing the amount of insulin released at high glucose (20 mmol/l) by that released at low glucose $(2.8 \mathrm{mmol} / \mathrm{l})$ 
blood glycaemia at 15,30 and $60 \mathrm{~min}$ post bolus administration of dextrose compared to controls. At $60 \mathrm{~min}$ this trend was statistically significant $(p<0.05)$ (Fig. 2). Insulin content of grafts by organ extraction showed decreased insulin content in sirolimus-treated animals. However, due to large variability, these differences were not statistically significant. Control grafts yielded $90.88 \pm 47(n=6) \mu \mathrm{g}$ insulin/graft, whereas sirolimus-treated grafts yielded $4.5 \pm 2.5(n=6) \mu \mathrm{g}$ insulin/graft.

To examine the effect of sirolimus on pancreatic islet function, we injected naïve non-diabetic mice with sirolimus $(0.2 \mathrm{mg} / \mathrm{kg}$, i.p.) daily for 26 days. Sirolimus content of whole blood was $37.03 \pm 4.0 \mathrm{ng} / \mathrm{ml}$ following the injection regime. We found no differences in daily blood glucose levels (Fig. 3) or pancreatic insulin content between sirolimus-treated and control mice. Pancreatic organ extraction for insulin content yielded $27.15 \pm 2.9 \mu \mathrm{g} /$ pancreas in control-treated animals and $24.06 \pm 1.5 \mu \mathrm{g} /$ pancreas in sirolimus injected animals. OGTTs, however, showed that at 30,60,90 and 120 min sirolimus-treated mice had significantly higher blood glucose than controls at matched timepoints (Fig. 3). Sirolimus-treated mice also showed a tendency towards increased weight gain relative to controls, with the difference between start and end

a

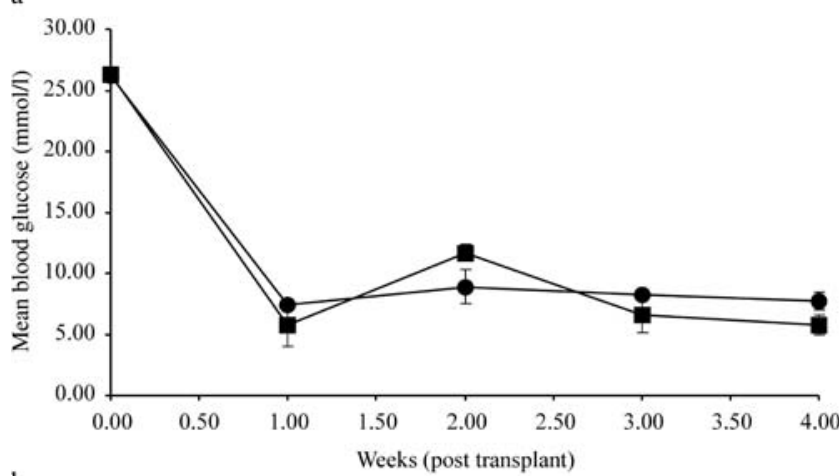

b

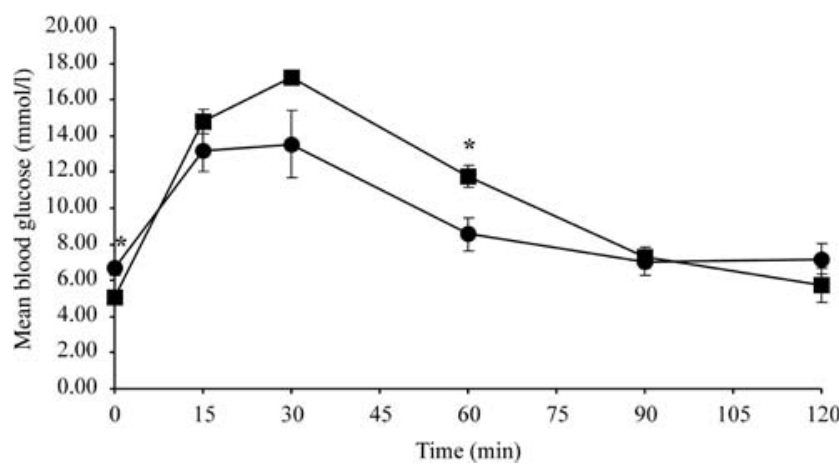

Fig. 2 a The effect of sirolimus on daily blood glucose values of syngeneic BALB/c transplants islet grafts. b Blood glucose values during oral administration of glucose to syngeneically transplanted BALB/c mice, 26 days post transplantation. Comparison of control mice $(\bullet ; n=3)$ with those receiving daily injection of sirolimus $(\boldsymbol{\bullet} ; n=5)$, i.p. ${ }^{*} p<0.05$ vs control
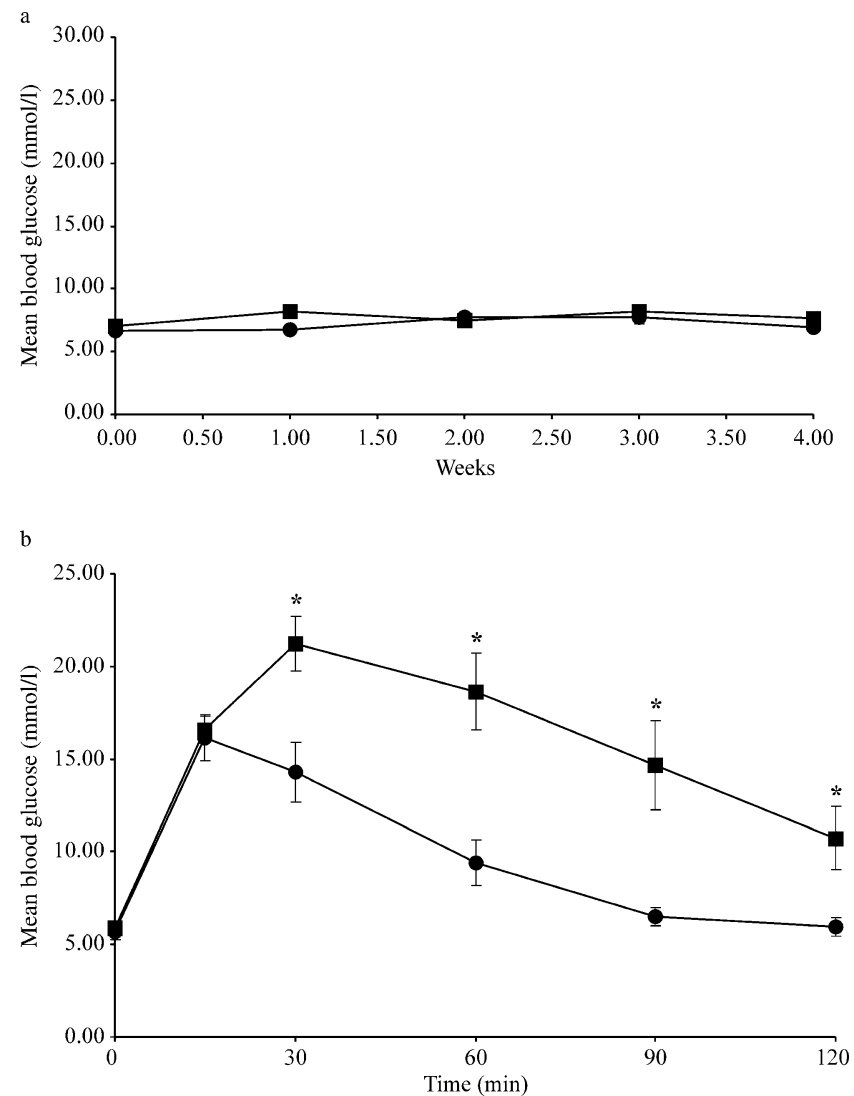

Fig. 3 a The effect of sirolimus on daily blood glucose values of naïve BALB/c mice. b Blood glucose values during oral administration of glucose to naïve BALB/c mice. Comparison of age-matched control mice $(\bullet ; n=11)$ with those receiving daily injection of sirolimus $(\boldsymbol{\square} ; n=11)$, i.p. ${ }^{*} p<0.05$ vs control

weights approaching significance (control $0.30 \pm 0.3$, sirolimus $1.49 \pm 0.5 ; p=0.078)$.

\section{Discussion}

Prior to this study the effect of sirolimus on pancreatic ductal cell proliferation was not known. We have evaluated the effect of sirolimus on ductal cell expansion, islet function and the in vivo function of islet grafts and pancreas. We found that in HDCs and NPIs, which contain $57 \%$ ductal cells, cell expansion was inhibited by 50 and $33 \%$, respectively, relative to untreated controls. These results are not surprising since sirolimus interacts with the FK506 binding protein intracellular binding proteins. The sirolimus-FK506 binding protein complex binds directly with mTOR and blocks its function. By inhibiting mTOR function, the protein translation necessary for cell growth and proliferation is inhibited and sirolimus halts the cell cycle in the G1 phase [35]. We observed that porcine ductal cells are more resilient to sirolimus than HDCs, a finding of clinical importance for xenotransplantation. If porcine 
tissue shows enhanced resilience to the negative effects of immunosuppressive drugs such as sirolimus, the graft longevity of porcine cells may be enhanced compared with human cell equivalents.

We found that sirolimus-treated HDCs did not show increased apoptosis relative to controls following 6 days of drug treatment. Although we did not culture our cells with $\left[{ }^{3} \mathrm{H}\right]$ thymidine, it has been shown that in human preadipocytes sirolimus inhibits proliferation as measured by this method [36]. The absence of elevated apoptosis in our study, coupled with the absence of proliferation reported by others [36], suggests that the decreased cell number within our sirolimus-treated cultures is probably primarily due to an inhibition of ductal proliferation. When HDCs were cultured with sirolimus, cell viability decreased to below that of time 0 (Fig. 1), indicating that sirolimus treatment induced cellular toxicity possibly by an early induction of apoptosis or necrotic cell death prior to day 6 , and thus was not detected when we assessed our cultures at day 6. In addition to its anti-proliferative properties, sirolimus has been shown by others to exhibit cellular toxicity, with a reduction of islet viability as measured by MTT and Calcein assay occurring at high concentrations (100 ng/ml) [6].

Clinically, patients receiving higher numbers of ductal cells have better long-term graft function despite sirolimus treatment, indicating that the high number of ductal cells present in islet grafts is sufficient to overcome the antiproliferative effects of sirolimus. However, sustained treatment with sirolimus may have an antiproliferative effect that is sufficient to diminish graft function as observed over time [1].

To study the systemic effects of sirolimus, mouse islets were transplanted beneath the kidney capsule of diabetic $\mathrm{BALB} / \mathrm{c}$ mice. Sirolimus-induced changes were observed in the OGTT profile, with mice showing elevated blood glycaemia during the glucose challenge followed by a return of levels to normal by the end of the test period.

The observed differences in OGTT profile may be due to poor vasculature caused by inhibition of angiogenesis, altered islet function resulting from ectopic transplantation, inhibition of islet function or reduced ductal proliferation. To determine if differences were due to poor vasculature or ectopic site, we treated naïve mice with daily injections of sirolimus. These mice had normal daily blood glucose, but also showed exacerbated changes in blood glucose regulation upon OGTT testing. The sirolimus content of whole blood from these mice was $37.03 \pm 4.0 \mathrm{ng} / \mathrm{ml}$, which is higher than the initial trough target levels of 10 to $12 \mathrm{ng} / \mathrm{kg}$ in human islet transplant recipients. We feel, however, that the high levels of sirolimus to which the animals are exposed may accurately represent the high peak drug concentrations within the portal circulation, to which human and large animal islet grafts are exposed after being infused into the recipient liver [37]. Similar decreases in insulin response to glucose have been reported in an allograft porcine model of islet transplantation and in the clinical setting of patients who receive islet transplantation $[27,38]$. In both reports transplant recipients received sirolimus as part of their immunosuppressive regime and demonstrated elevated glucose following a glucose challenge test.

The sustained hyperglycaemia observed during OGTT testing, together with increased weight gain in sirolimustreated animals, suggests the initiation of insulin resistance in these animals. Sirolimus decreases the phosphorylation of serine 307 on IRS-1 in adipocytes, thereby inhibiting efficient insulin signalling in human adipocytes and mimicking what is seen with type 2 diabetes [39]. In our work we did not observe any effect on GSIS in human or porcine islets exposed to sirolimus in vitro. However, altered OGTT profiles were observed in vivo when sirolimus was administered to naïve mice and diabetic mice transplanted with syngeneic islet grafts. It is likely that sustained hyperglycaemia during OGTT testing resulted from an inhibition of efficient signalling in the adipocyte, leading to decreased efficiency of insulin-induced glucose sequestration by the adipocyte. It is also known that sirolimus inhibits insulin-induced synthesis of glycogen and protein in muscle [40,41], which may also contribute to the sustained hyperglycaemia observed by us in vivo but not in vitro upon hyperglycaemic challenge.

This study presents convincing evidence that sirolimus inhibits the proliferation of pancreatic ductal cells and alters GSIS in vivo. Therefore, by administering sirolimus to islet transplant recipients, we are probably inhibiting long-term graft function by decreasing ductal neogenesis and inducing insulin resistance. Future work in this area will include the investigation of new immunosuppressive drugs and tolerance induction protocols to replace the use of sirolimus for effective immunosuppression. Indeed, there are many promising new drugs, such as sphingosine-1-phosphate receptor agonists or the costimulation inhibitor belatacept, which are now undergoing clinical trial and which may provide specific $\mathrm{T}$ cell inhibition with fewer diabetogenic side effects $[42,43]$.

Acknowledgements C. T. Bussiere is supported in part by a grant from the Stem Cell Network (Canadian Centres of Excellence). J. R. T. Lakey and G. S. Korbutt are recipients of scholarships from the Canadian Diabetes Association as well as the Alberta Heritage Foundation for Medical Research. G. S. Korbutt also has a Career Development Award from the Juvenile Diabetes Research Foundation. A. M. J. Shapiro is a clinical investigator of the Alberta Heritage Foundation for Medical Research and holds the Clinical Research Chair in Transplantation (CIHR/Wyeth). Funding for this project was provided by grants from the Alberta Foundation for Diabetes Research, Juvenile Diabetes Research Foundation, and the Canadian Institute for Health Research. 
The authors thank D. Colwell for assistance with figures and formatting as well as M. McCammon, E. Henry, L. Elder, K. Seeburger and J. Lyon for technical assistance and data collection. They also thank the staff of the Clinical Islet Laboratory (University of Alberta) and the H.O.P.E. program for identifying and procuring organs from cadaveric donors.

\section{References}

1. Ryan EA, Paty BW, Senior PA et al (2005) Five-year follow-up after clinical islet transplantation. Diabetes 54:2060-2069

2. Shapiro AM, Lakey JR, Ryan EA et al (2000) Islet transplantation in seven patients with type 1 diabetes mellitus using a glucocorticoid-free immunosuppressive regimen. N Engl J Med 343:230-238

3. Seufferlein T, Rozengurt E (1996) Rapamycin inhibits constitutive p70s6k phosphorylation, cell proliferation, and colony formation in small cell lung cancer cells. Cancer Res 56:3895-3897

4. Fuhrer DK, Kobayashi M, Jiang H (2001) Insulin release and suppression by tacrolimus, rapamycin and cyclosporin $\mathrm{A}$ are through regulation of the ATP-sensitive potassium channel. Diabetes Obes Metab 3:393-402

5. Paty BW, Harmon JS, Marsh CL, Robertson RP (2002) Inhibitory effects of immunosuppressive drugs on insulin secretion from HIT-T15 cells and Wistar rat islets. Transplantation 73:353-357

6. Bell E, Cao X, Moibi JA et al (2003) Rapamycin has a deleterious effect on MIN-6 cells and rat and human islets. Diabetes 52:2731-2739

7. Polastri L, Galbiati F, Bertuzzi F et al (2002) Secretory defects induced by immunosuppressive agents on human pancreatic beta-cells. Acta Diabetol 39:229-233

8. Hui H, Khoury N, Zhao X et al (2005) Adenovirus-mediated XIAP gene transfer reverses the negative effects of immunosuppressive drugs on insulin secretion and cell viability of isolated human islets. Diabetes 54:424-433

9. Finegood DT, Scaglia L, Bonner-Weir S (1995) Dynamics of betacell mass in the growing rat pancreas. Estimation with a simple mathematical model. Diabetes 44:249-256

10. Dor Y, Brown J, Martinez OI, Melton DA (2004) Adult pancreatic beta-cells are formed by self-duplication rather than stem-cell differentiation. Nature 429:41-46

11. Gu G, Brown JR, Melton DA (2003) Direct lineage tracing reveals the ontogeny of pancreatic cell fates during mouse embryogenesis. Mech Dev 120:35-43

12. Lammert E, Cleaver O, Melton D (2003) Role of endothelial cells in early pancreas and liver development. Mech Dev 120:59-64

13. Sander M, German MS (1997) The beta cell transcription factors and development of the pancreas. J Mol Med 75:327-340

14. Bonner-Weir S, Sharma A (2002) Pancreatic stem cells. J Pathol 197:519-526

15. Peck AB, Cornelius JG, Schatz D, Ramiya VK (2002) Generation of islets of Langerhans from adult pancreatic stem cells. J Hepatobiliary Pancreat Surg 9:704-709

16. Ianus A, Holz GG, Theise ND, Hussain MA (2003) In vivo derivation of glucose-competent pancreatic endocrine cells from bone marrow without evidence of cell fusion. J Clin Invest 111:843-850

17. Kodama S, Kuhtreiber W, Fujimura S, Dale EA, Faustman DL (2003) Islet regeneration during the reversal of autoimmune diabetes in NOD mice. Science 302:1223-1227

18. Zorina TD, Subbotin VM, Bertera S et al (2003) Recovery of the endogenous beta cell function in the NOD model of autoimmune diabetes. Stem Cells 21:377-388
19. Street CN, Lakey JR, Shapiro AM et al (2004) Islet graft assessment in the Edmonton protocol: implications for predicting long-term clinical outcome. Diabetes 53:3107-3114

20. Abraham RT, Wiederrecht GJ (1996) Immunopharmacology of rapamycin. Annu Rev Immunol 14:483-510

21. Bruns CJ, Koehl GE, Guba M et al (2004) Rapamycin-induced endothelial cell death and tumor vessel thrombosis potentiate cytotoxic therapy against pancreatic cancer. Clin Cancer Res 10:2109-2119

22. Lieberthal W, Fuhro R, Andry CC et al (2001) Rapamycin impairs recovery from acute renal failure: role of cell-cycle arrest and apoptosis of tubular cells. Am J Physiol Renal Physiol 281:F693-F706

23. Seufferlein T, Rozengurt E (1996) Rapamycin inhibits constitutive p70s6k phosphorylation, cell proliferation, and colony formation in small cell lung cancer cells. Cancer Res 56:3895-3897

24. Zhu J, Wu J, Frizell E et al (1999) Rapamycin inhibits hepatic stellate cell proliferation in vitro and limits fibrogenesis in an in vivo model of liver fibrosis. Gastroenterology 117:1198-1204

25. Zohlnhofer D, Nuhrenberg TG, Neumann FJ et al (2004) Rapamycin effects transcriptional programs in smooth muscle cells controlling proliferative and inflammatory properties. Mol Pharmacol 65:880-889

26. Korbutt GS, Elliott JF, Ao Z, Smith DK, Warnock GL, Rajotte RV (1996) Large scale isolation, growth, and function of porcine neonatal islet cells. J Clin Invest 97:2119-2129

27. Kin T, Korbutt GS, Kobayashi T, Dufour JM, Rajotte RV (2005) Reversal of diabetes in pancreatectomized pigs after transplantation of neonatal porcine islets. Diabetes 54:1032-1039

28. Cardona K, Korbutt GS, Milas Z et al (2006) Long-term survival of neonatal porcine islets in nonhuman primates by targeting costimulation pathways. Nat Med 12:304-306

29. Rose NL, Palcic MM, Shapiro AM, Lakey JR (2004) Endogenous pancreatic enzyme activity levels show no significant effect on human islet isolation yield. Cell Transplant 13:153-160

30. Lakey JR, Warnock GL, Shapiro AM et al (1999) Intraductal collagenase delivery into the human pancreas using syringe loading or controlled perfusion. Cell Transplant 8:285-292

31. Street CN, Lakey JR, Rajotte R et al (2004) Enriched human pancreatic ductal cultures obtained from selective death of acinar cells express pancreatic and duodenal homeobox gene-1 age dependently. The Review of Diabetic Studies 1:66-79

32. Ohzato H, Gotoh M, Monden M, Dono K, Kanai T, Mori T (1991) Improvement in islet yield from a cold-preserved pancreas by pancreatic ductal collagenase distention at the time of harvesting. Transplantation 51:566-570

33. Bonner-Weir S, Taneja M, Weir GC et al (2000) In vitro cultivation of human islets from expanded ductal tissue. Proc Natl Acad Sci USA 97:7999-8004

34. Korbutt GS, Pipeleers DG (1992) Cold storage of rat pancreas before purification of islet beta-cells. Diabetes 41:299-307

35. Sehgal SN (2003) Sirolimus: its discovery, biological properties, and mechanism of action. Transplant Proc 35:7S-14S

36. Bell A, Grunder L, Sorisky A (2000) Rapamycin inhibits human adipocyte differentiation in primary culture. Obes Res 8:249-254

37. Shapiro AM, Gallant HL, Hao EG et al (2005) The portal immunosuppressive storm: relevance to islet transplantation? Ther Drug Monit 27:35-37

38. Markmann JF, Deng S, Huang X et al (2003) Insulin independence following isolated islet transplantation and single islet infusions. Ann Surg 237:741-749

39. Danielsson A, Ost A, Nystrom FH, Stralfors P (2005) Attenuation of insulin-stimulated insulin receptor substrate-1 serine 307 phosphorylation in insulin resistance of type 2 diabetes. J Biol Chem 280:34389-34392

40 Azpiazu I, Saltiel AR, DePaoli-Roach AA, Lawrence JC (1996) Regulation of both glycogen synthase and PHAS-I by insulin in rat 
skeletal muscle involves mitogen-activated protein kinase-independent and rapamycin-sensitive pathways. J Biol Chem 271:5033-5039

41. Hurel SJ, Rochford JJ, Borthwick AC et al (1996) Insulin action in cultured human myoblasts: contribution of different signalling pathways to regulation of glycogen synthesis. Biochem J $320: 871-877$
42. Adams AB, Shirasugi N, Durham MM et al (2002) Calcineurin inhibitor-free CD28 blockade-based protocol protects allogeneic islets in nonhuman primates. Diabetes 51:265-270

43. Tedesco-Silva H, Mourad G, Kahan BD et al (2005) FTY720, a novel immunomodulator: efficacy and safety results from the first phase $2 \mathrm{~A}$ study in de novo renal transplantation. Transplantation 79:1553-1560 